Provided for non-commercial research and education use. Not for reproduction, distribution or commercial use.

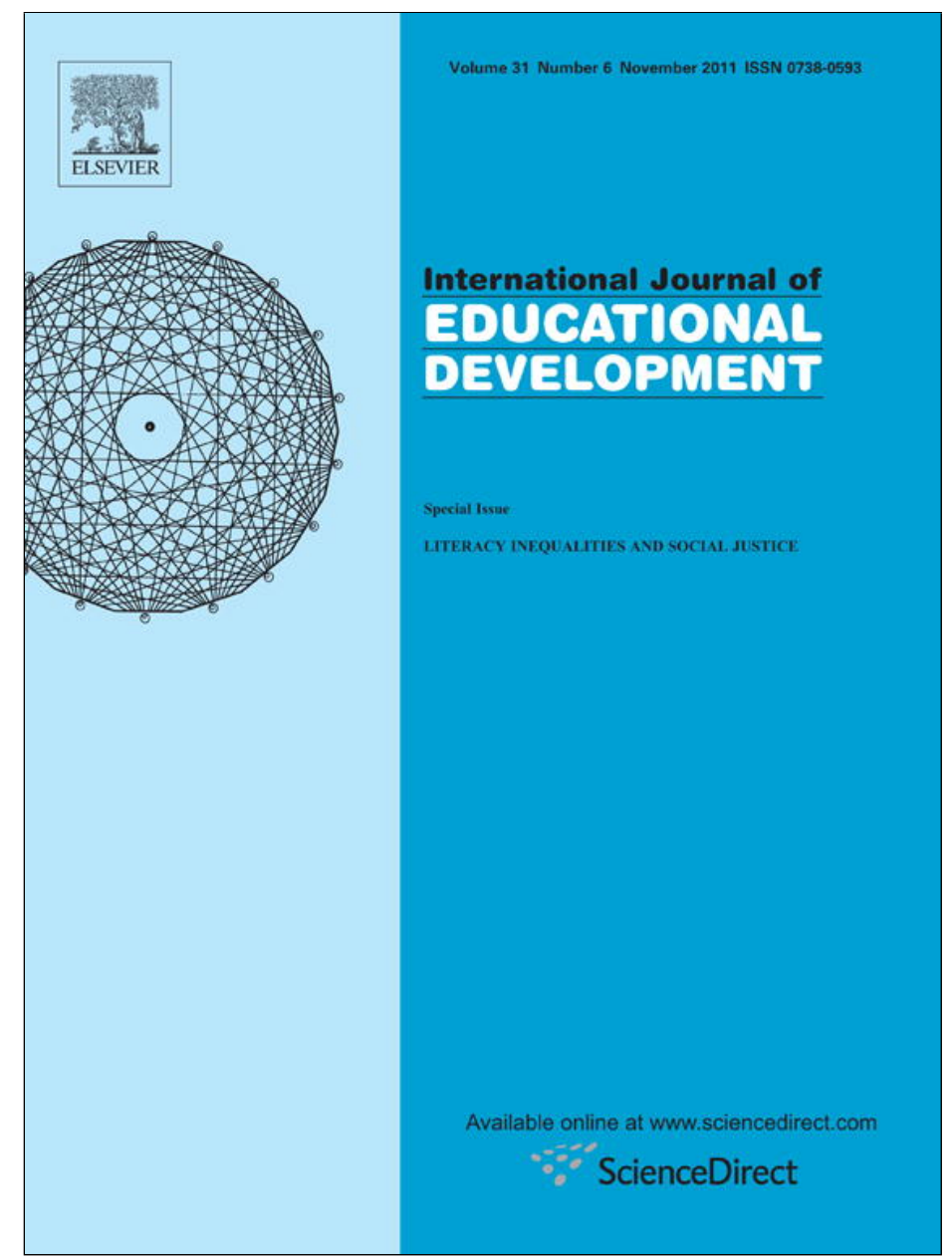

This article appeared in a journal published by Elsevier. The attached copy is furnished to the author for internal non-commercial research and education use, including for instruction at the authors institution and sharing with colleagues.

Other uses, including reproduction and distribution, or selling or licensing copies, or posting to personal, institutional or third party websites are prohibited.

In most cases authors are permitted to post their version of the article (e.g. in Word or Tex form) to their personal website or institutional repository. Authors requiring further information regarding Elsevier's archiving and manuscript policies are encouraged to visit:

http://www.elsevier.com/copyright 


\title{
Confronting poverty and educational inequalities: Madrasas as a strategy for contesting dominant literacy in rural Bangladesh
}

\author{
Nitya Rao ${ }^{\mathrm{a}, *}$, Munshi Israil Hossain ${ }^{\mathrm{b}}$ \\ a School of International Development, University of East Anglia, Norwich NR4 7TJ, United Kingdom \\ ${ }^{\mathrm{b}}$ University of Rajshahi, Bangladesh
}

\section{A R T I C L E I N F O}

\section{Keywords:}

Comparative education

Madrasas

Poverty

Language

Gender

Bangladesh

\begin{abstract}
A B S T R A C T
In a context of globalisation and the rapid expansion of low-paid 'global' jobs, formal schooling is no longer perceived as contributing to the acquisition of skills that are appropriate or even relevant to active engagement with the new opportunities. Based on empirical material from a village in Bangladesh, this paper explores the role of madrasa education in challenging the dominant paradigm of learning embedded in formal secular schooling. Despite charges of low quality and traditionalism, local narratives reveal how madrasa learning is used to negotiate and transform inequalities, both in material and social terms. Madrasa education is cheaper, and addresses issues of poverty, but the narratives also emphasise learning the Arabic language, seen to facilitate male overseas migration to the Gulf countries, a channel for upward social and economic mobility. In a context of global competition that supports individualism, a focus on character and morality as represented through an Islamic identity, alongside communitarian values, is seen as important for maintaining a degree of social cohesion and is hence socially valued. Reading and reciting the Quran are also viewed as essential traits for a woman, enabling her to appropriately socialise her children in the absence of her migrant husband. One finds here a simultaneous process of contestation and resistance, seeking successful occupational trajectories and social recognition for men, while at the same time contributing to the reproduction of gendered inequalities.
\end{abstract}

(c) 2011 Elsevier Ltd. All rights reserved.

\section{Introduction}

Post 9/11, madrasas (Islamic schools) have been a focus of policy interest globally, viewed as they are as promoting Islamic extremism and militancy, and serving as a recruiting ground for terrorism. Some however argue that they play an important role in education provision in several Muslim countries where state infrastructure hardly exists and poverty makes private provision beyond the reach of the poor (Blanchard, 2008). These views have led to a concern for madrasa reform that seeks to displace potentially extremist religious tendencies within madrasas by ensuring a degree of state control over the curriculum (Bano, 2007), alongside setting in place mechanisms for monitoring and accountability (Hartung and Reifeld, 2006). While Bangladesh has been unique in South Asia in its regulation of registered madrasas since the 1980s, the reform agenda has regained prominence in a context where madrasa education has been rapidly expanding, rather than being replaced by secular schools. An additional concern here is that madrasas should provide an education that

\footnotetext{
* Corresponding author. Tel.: +44 01603592333; fax: +44 01603451999.

E-mail address: n.rao@uea.ac.uk (N. Rao).
}

can enable its students engage with the modern economy and with processes of globalisation, rather than being confined to religious work. This is crucial given that the export-oriented garments industry and remittances from overseas migrants account for about 20 per cent of the country's GDP (Rahman et al., 2009).

While the compulsions for madrasa reform are both political and socio-cultural, in this paper, I use ethnographic material from research in Achingaon, ${ }^{1}$ a Bangladeshi village, to explore the challenges posed by madrasa education to the dominant paradigm of learning embedded in formal, secular schooling. It needs to be noted that though madrasas are largely perceived as traditional institutions, lacking a modern outlook, wherein rote learning of religious scriptures leaves little room for creativity or critical thinking, there is in reality a great diversity within this sector, ranging from the purely religious Quomi madrasas to the aliya madrasas which combine general and religious education.

Local narratives, however, portray the madrasas as a positive alternative for enhancing economic opportunities and social standing, as well as challenging inequalities, in particular around poverty, with an emphasis on the dignity of labour, language and

\footnotetext{
${ }^{1}$ All names have been changed in the paper.
} 
moral character. Catering largely to the poor, literacy and language learning in the madrasas are used as resources by them to construct a positive social identity and give meaning to their lives in relation to the social structures and cultural systems within which they are embedded. As Kress (1996: 14) points out, there are two key aspects in terms of meaning-making which are at play here, the representational and the communicational. The first involves the cultural construction of their learning as including the moral values of sacrifice, hard work and patience, while the latter reflects the use of their literacy and the meanings accorded to it across different spatial and social contexts, such as employment in the less skilled labour markets of the Gulf States. This notion of literacy and learning moves beyond discrete and decontextualised skills to understanding it as a dynamic set of activities, embracing a way of life and their very sense of personhood.

I focus in this paper on both strands of meaning-making in relation to madrasa education and its perceived links to the occupational trajectories of men. I argue that there is a carefully crafted discourse around the representation of madrasas that systematically highlights the differences with secular, state provision, in order to challenge its educational hegemony, in the process serving both the practical and power needs of the students. Yet, the understanding of inequalities remains gendered, with a growing conservatism visible amongst madrasa graduates in relation to women's roles, supporting a traditional patriarchal social structure where boys are preferred and supported both for higher education and employment, while girls play a home-making role (Asadullah and Chaudhury, 2010). ${ }^{2}$ In the next section, I discuss the historical roots and the current basis for valuing madrasa education and go on then to discuss the meanings ascribed to it, and its uses.

\section{Education and social identity}

Educational systems are about knowledge and skills, but also about the ways in which people conceive of themselves, their identities and social positioning. They are ultimately about power and its negotiation in society. As Street notes in relation to the ways in which people address issues of reading and writing, "Literacy, in this sense, is always contested, both its meaning and its practices, hence particular versions of it are always 'ideological', they are always rooted in a particular worldview and a desire for that view of literacy to dominate and marginalise others" (2001: 78 ). Ultimately, these systems are the crystallisation of the political ethos of the State and its power, ideology and class character in relation to the larger society.

The 'modern' education system in the Indian subcontinent (which includes the current nation-states of India, Bangladesh and Pakistan), was over the last two hundred years, largely shaped by the imperatives of the colonial government as outlined in Macaulay's Minute on Indian Education in 1835 and detailed in Charles Wood's despatch of 1854 . The primary purpose of education was to create an elite class of Indians, who could participate in running the government of the country, loyal to and unquestioning of the colonial masters.

[34] I feel ... that it is impossible for us, with our limited means, to attempt to educate the body of the people. We must at present do our best to form a class who may be interpreters between us and the millions whom we govern ... a class of persons Indian in blood and colour, but English in tastes, in

${ }^{2}$ Rahman (2004: 313) too found in his survey of schools in Pakistan (Urdumedium, English medium and Sunni madrasas) that while madrasa education does not automatically translate into militancy, the students do support an aggressive foreign policy, are intolerant of religious minorities and do not support equal rights for men and women. morals and in intellect. To that class we may leave it to refine the vernacular dialects of the country, to enrich those dialects with terms of science borrowed from the Western nomenclature, and to render them by degrees fit vehicles for conveying knowledge to the great mass of the population. http:// www.mssu.edu/projectsouthasia/history/primarydocs/education/Macaulay001.htm accessed on 23 March 2009.

Education here is closely connected to the construction of a particular social identity and set of power relations - a class of people fluent in the English language, with tastes, morals and lifestyles in tune with the cultural elites at that time, namely, the colonial rulers. Several assumptions underlie the above text, pointing to the ideology driving the education system. First, there is an acknowledgement that providing basic education to the entire populace would be both an expensive and difficult task. Hence this needed to be a phased process, trickling down gradually from the elite to the masses, in other words, inequality in access to education was accepted and built into the educational policy and systems. Second, education in English language was seen as crucial for the 'intellectual improvements of those classes of people who have the means of pursuing higher studies' and could thereafter participate in government, and such English language education was not necessarily appropriate for the mass of people. Clearly, education, and English language more specifically, becomes a selective device to legitimise processes of domination and control, of creating class and power divisions in society on the basis of linguistic competence, and at the same time reinforcing prevalent social inequalities, with English becoming 'the possession of educated and affluent groups around the world' (Kress, 1996: 2).

A third related issue was the supposed linkage between the English language and science - there was an attempt to contrast both Arabic (Islamic) and Sanskrit (Hindu) education with notions of secularism, modernity and development associated with science and reason. A hierarchy of education systems was established with western, English education seen as 'modern' and the road to upward mobility compared to Islamic (or indeed Hindu) education, ${ }^{3}$ such that the latter was gradually abandoned by the elite and left to poor students, mainly of rural origin (Hefner, 2007: 18). In the contemporary context too, this link between Islamic education and the poor persists and in fact drives the fear of madrasas, as the poor and unemployed are seen as easy targets and recruiting grounds for terrorist organisations.

A close correlation was also established between formal educational credentials and employment opportunities, ignoring the continuum of learning through time and space, crossing the boundaries between educational institutions and the everyday lives of learners (Street, 2005). Independence from colonial rule was won in 1947, yet this educational legacy has continued. Despite post-Independence efforts to promote mother-tongue education on the one hand and vocational and skills education on the other, alongside the exposure to a range of learning opportunities in a global context, basic mindsets in relation to educational and employment hierarchies have been hard to change. Private, English-medium schools for the elite, continue

\footnotetext{
${ }^{3}$ Before the advent of the British, four types of educational institutions existed in much of India: the Sanskrit Chatushpadi or Toll and Madrasas as institutions of higher learning, and Pathashalas and Maktabs as elementary schools. Apart from reading, writing and arithmetic, they imparted practical knowledge like bookkeeping and maintaining land records. These schools were a part of village life and the teachers were like public servants. The medium of instruction was the local language. http://www.educationbihar.in/csscreport/Chapter1_The\%20Evolution\%20of\%20School\%20Education\%20in\%20Bihar-\%20A\%20Historical\%20Perspective.pdf accessed on $27 / 08 / 2009$.
} 
to be seen as a pathway to white-collar employment, but also integration with the elite global world and media which uses English as an international and not just colonial language, coexisting alongside public, vernacular language and religious schools for the poor, seen as sufficient for blue-collar and manual work (Munshi and Rosenzweig, 2003).

Bangladesh, with its strong language movement in the 1950s and 1960s, culminating in its formation as a separate nation-state in 1971, is perhaps the exception in the subcontinent in terms of its exclusion of English. While framed as resistance to the colonial order, the result, however, was a rejection of both English and Urdu (official language of Pakistan of which it was a part), and an exclusive focus on Bangla. Guha (2009), in discussing some of the problems of present-day monolingualism, notes that the loss of a language carries within it a loss of exposure to multicultural values and global ideas, apart from a social and emotional disconnect between the elite and the masses. He further notes that while the earlier generation of scholars and leaders were bilingual, both functionally and emotionally, the present generation is largely monolingual, widening the divide between the urban, Englishspeaking elite and the rural, vernacular-speaking poor.

The globalisation of trade and production, migration, the spread of new technologies, in particular, information and communication technologies (such as the mobile phone) over the last two decades, has however resulted in generating acceptance for alternate forms of language and learning, that seek to negotiate, resist and transform dominant values, meanings and relationships (Gee, 2000). Education is now seen to have at least two goals, one occupational (instrumental) and the other in terms of shaping one's cultural identity (Metcalf, 2007), apart from its intrinsic value to a person's self-worth. Widespread labour migration to the Gulf States has created the need for a different linguistic resource some knowledge of the Arabic language that can facilitate basic communication and survival in the workplace. A clear sense of cultural identity that can help the migrants negotiate unequal power relationships within globalised work cultures has also become essential.

While a bureaucratic job in government is still seen and valued as a 'real job' for the security and status it provides, with rapidly reducing opportunities in the public sector, and shift in the organisation of labour towards increasing flexibilisation, characterised by informal or semi-formal employment relations (Mitter, 1994), one finds people, especially the rural poor, increasingly questioning and joking about this orthodoxy, claiming that they prefer to be free and self-employed rather than becoming a naukar (servant), even of the State. Adapting to this change in the organisation of work has led to a focus on self-reliance rather than dependence on others, including the government (Lukens-Bull, 2001 ), establishing the dignity of all forms of labour when honestly undertaken. Several migrant men noted that in order to fulfill their responsibility towards their families they undertook any type of work, however menial, demeaning or difficult.

The focus on steadfastness and duty is one of the key messages of madrasa education, and one that is positively viewed in the local context. In the process of legitimising insecure employment and providing dignity to a range of occupations, as against the primacy given to public sector employment within the secular school system, an alternate identity is also developed based on a notion of morality that values their learning, hard work and contributions to the family and community. While madrasa education may be limited in academic terms, when measured on an autonomous, competency-based yardstick, it provides the learner with the identity of being a religious-minded, moral person; qualities of tolerance, sacrifice and care are valorised in a context of uncertain livelihoods, and community ownership and contributions emphasised (Street, 1993; Barton and Hamilton, 2000).
Before moving on to a detailed discussion of the representational and communicational value of madrasa education to the poor, I briefly describe the village context, both in terms of education as well as the work and livelihood opportunities that are available. The village was selected for three main reasons: first, easy access to secondary education in the vicinity provided both through an aliya madrasa and a secular state school; second, high levels of out-migration; and third, the existence of baseline data from the ESRC-funded Wellbeing and Development Research Centre. Field work was conducted between 2006 and 2008, and the data presented in this paper largely draws on 16 in-depth interviews, eight each with men and women, focus group discussions with teachers, parents and young people, and a household census.

\section{The context}

Achingaon is a relatively poor village with 310 Muslim households located in Manikganj district, west of the capital city of Dhaka. ${ }^{4}$ Over the past $10-15$ years, with improving communication and transport facilities and the rapid expansion of employment opportunities in the garment factories and welding workshops in and around Dhaka, and overseas, especially in the Gulf countries, ${ }^{5}$ the consequent inflow of remittances has led to a shift in people's employment choices, lifestyles and most importantly attitudes towards education. With the additional awareness created through the mass literacy campaigns as well as the rapid spread of mobile phones, people aspire to move from agriculture into other occupations, which could give them both higher returns and greater control over their own labour. The household census revealed that while 32 per cent of adult men are still engaged in agriculture, and another 21 per cent in rickshaw/van pulling and day labouring, a large number have diversified into small business (10 per cent), factory work ( 10 per cent), overseas migration ( 6 per cent), teaching and religious work (5.5 per cent) and others ( 15 per cent). Many of these involve moving out of the village for varying lengths of time, in fact, 27 per cent or 118 men are currently migrant. Except for a small number of young women who are employed in the garment factories, a majority of women are classified as home-makers. While offering opportunities, migrant livelihoods also require different skills, including the capacity for long hours of hard work in difficult conditions, patience and the humility to bear insults, the ability to deal with unfamiliar language settings in the workplace, alongside dealing with loneliness that comes with the inability to communicate through speech.

In terms of educational provision, Achingaon has a state-run primary school, ${ }^{6}$ two non-governmental private primary schools run by BRAC and two madrasas, the Aliya being state-aided and the hafezia not. ${ }^{7}$ Table 1 presents background information on the share of different types of schools and madrasas in the total educational enrolment in the village. At the primary level, while half the children go to the government primary school, the rest are divided between the maktab and BRAC schools. At the secondary level

\footnotetext{
${ }^{4}$ Manikganj district as a whole is better off than other districts in northern and southern Bangladesh, with only 25 per cent of its population below the poverty line (BBS, 2009). Yet, in Achingaon, 48 per cent of households are landless and 49 per cent have small land-holdings (less than 2 acres). Relatively few (10 per cent) have higher education or are employed in white-collar jobs (less than 5 per cent). While almost half the households own mobile phones, only one person owns a motorbike, and no one a car (Rao, 2009a).

5 Over 75 per cent of overseas migrants, about 6.7 million from 1976 to 2009, were in the Gulf, half of them in Saudi Arabia http://www.bmet.org.bd/BMET/ stattisticalDataAction accessed on 13/4/10.

${ }^{6}$ The primary school, established through local collective action in 1972, gained recognition in 1984.

${ }^{7}$ Hafezia is one type of Quomi madrasa, the others being the Nurania and Forqania.
} 
Table 1

Type of education provision by gender.

\begin{tabular}{|c|c|c|c|c|c|c|}
\hline \multirow[t]{2}{*}{ Type of institution } & \multicolumn{2}{|c|}{ Male } & \multicolumn{2}{|c|}{ Female } & \multicolumn{2}{|c|}{ Total } \\
\hline & No. & $\%$ & No. & $\%$ & No. & $\%$ \\
\hline \multicolumn{7}{|l|}{ Primary } \\
\hline Kindergarten & 2 & 2.5 & 1 & 1.5 & 3 & 2 \\
\hline Government primary school & 47 & 55 & 30 & 39.5 & 77 & 48 \\
\hline NGO BRAC school & 14 & 16.5 & 22 & 29 & 36 & 22 \\
\hline Maktab (primary madrasa) & 22 & 26 & 23 & 30 & 49 & 28 \\
\hline Sub-total & 85 & 100 & 76 & 100 & 161 & 100 \\
\hline \multicolumn{7}{|l|}{ Secondary } \\
\hline Government secondary school & 19 & 28 & 18 & 29.5 & 37 & 29 \\
\hline Aliya madrasa & 40 & 59 & 42 & 69 & 82 & 63.5 \\
\hline Hafezia madrasa & 4 & 6 & 0 & 0 & 4 & 3 \\
\hline College & 5 & 7 & 1 & 1.5 & 6 & 4.5 \\
\hline Sub-total & 68 & 100 & 61 & 100 & 129 & 100 \\
\hline Total & 153 & & 141 & & 290 & \\
\hline
\end{tabular}

there is a shift in favour of the aliya madrasa, which apart from providing a combination of religious and general education is also the only provider of post-primary education within the village, as the secular secondary school is located in the market town of Sujapur, $2.5 \mathrm{~km}$ away. The latter maintains high academic standards, as evidenced by the fact that several of its students received merit scholarships. Despite offering incentives for girls in terms of stipends for secondary education, dropouts however persist. Enrolment and transition data collected from the Sujapur high school revealed that out of 143 boys and 101 girls enrolled in grade 6 in 2001, only 61 boys and 28 girls completed grade 10 in 2005 , a completion rate of 42 per cent for boys and 27 per cent for girls. $^{8}$

The Aliya madrasa was set up by a former Union Parishad (local government) chairman from the village, a jute businessman, in 1984 , but became fully operational from 1990 . He wanted to build a religious school to promote moral education, yet realised the need for general literacy skills that could contribute to future employment. With his contacts in the government, he negotiated the setting up of an aliya madrasa, supported and regulated by the government. Here too, however, less than 40 per cent of students complete their secondary education, a majority dropping out after grade 8 or 9 . Precise figures however were not available. Yet in response to a conservative demand by a group of religious leaders and elites opposed to the chairman, in 1995, a hafezia madrasa was established on land donated by another rich businessman in the village. The school is residential, with 75 students (only four of them from the village), all male, and focuses on the learning of the Quran and other Islamic texts. It is run entirely through public donations, receiving no funds from the state. What one finds then is the co-existence of multiple educational practices and providers on the ground, with interconnections and competition not just between the secular school and the madrasas, but even between the madrasas, in terms of their relative contributions to occupational trajectories as well as identity construction.

Despite the Aliya madrasa teaching both secular and religious subjects, one of the key differences between the madrasas and the secular school is in terms of the background and training of teachers. Asadullah and Chaudhury (2010) point to the key role of teachers, who influence learning through their social interactions, not just the transaction of the curriculum. Female teachers in particular, can inspire social change, especially in a patriarchal society like Bangladesh, by subverting the stereotypes of domesticated women and presenting an alternate and equally respectable role model. This however is not visible in Achingaon,

\footnotetext{
${ }^{8}$ While net enrolment in secondary education was $45 \%$ in 2005 for Bangladesh as a whole, only half these students, boys and girls, survived the entire cycle, making for a completion rate of less than 20 per cent (Ahmed et al., 2007).
}

with both the madrasas having only male teachers (13 in the aliya and two in the hafezia). With the exception of three graduates in the Aliya madrasa, the rest have educational degrees from other madrasas in the country [ 4 have fazil (equivalent to BA), six have kamil (equivalent to MA) and two are Alim (HSC)]. Their educational backgrounds partly explain the absence of female teachers, as despite girls now forming roughly half the number of students in the aliya madrasas, ${ }^{9}$ their numbers decline at the fazil and kamil (graduate and postgraduate) levels, which specialise in religious education (Bano, 2007). This is in sharp contrast to the Sujapur high school, where out of 15 teachers, three are women. ${ }^{10}$ Only the teacher responsible for teaching religion has a madrasa degree (kamil), while the rest have BA (7), B.Sc. (4), B.Com (2) or MBA (1) degrees. 12 of them have received teacher training as against only four of the Aliya madrasa teachers.

\section{Madrasas in Bangladesh: making meaning of the learning process}

Madrasas are not new in Bangladesh, and as noted in Macaulay's Minute on Education, were a point of comparison with western education during the colonial period. While over a 1000 madrasas existed in the country at the time of independence in 1971, the attempt of the new, secular state was to emphasise Bengali language and ethnicity and reject Islamic identity as its central pillar. State emphasis was therefore on provision of secular education. This secularism was however short-lived and by 1988 , the Constitution was amended to make Islam the official state religion (Ellickson, 2002). Yet, during the 1980s, the effort was to modernise and regulate the existing madrasas, rather than expansion. The Madrasa Education Board was set up in 1979, and state incentives to cover 90 per cent of teacher salaries established. In 1985, dakhil and in 1987, Alim were recognised as equivalent to the Secondary and Higher Secondary School Certificate, respectively. Apart from about 9000 governmentregistered Aliya madrasas, estimates of the number of Quomi madrasas vary from 5000 to 15,000 , but as they are unregistered and unregulated by the State, exact data is not available. There are more than ten Quomi Madrasa Boards in Bangladesh that issue standard certificates to their students, expected to get jobs largely in the religious hierarchy, both within the country and in the Gulf States.

\footnotetext{
${ }^{9}$ With the extension of female secondary stipends to the Aliya madrasas in 1994, there has been a rapid growth in female enrolment (Asadullah and Chaudhury, 2008).

${ }^{10}$ Asadullah and Chaudhury (2010) find that only 9 per cent of madrasa teachers are women compared to 20 per cent in secular schools.
} 
During the last decade, madrasas have expanded rapidly throughout the country as an alternate channel of formal learning, especially for the poor, accounting now for 15 per cent of the total post-primary enrolments (Asadullah and Chaudhury, 2008). There is a strong political dimension to this expansion, both in terms of local and national party politics, but also the growing links with the Islamic states of the middle-east, through especially the large-scale provision of unskilled and semi-skilled labour. ${ }^{11}$ While there was an expansion of madrasas by 17 per cent (in contrast to 28 per cent growth of general schools) during the secular Awami League regime from 1996 to 2000, during the four party coalition government led by the Bangladesh Nationalist Party (BNP), under the leadership of Khaleda Zia from 2001 to 2005, the pace of growth was faster at 22 per cent in the number of madrasas receiving government aid as compared to a 10 per cent growth of general schools (Bangladesh Economic Review, 2006). There was an attempt by this coalition government, in 2005, to formalise the equivalence of the madrasa certifications at fazil and kamil levels with BA and MA degrees, respectively, but this was opposed both by educational experts and secular-minded intellectuals and political groupings, who saw this measure as a sign of conservative control by the Jamaat-e-Islami, one of the coalition partners. ${ }^{12}$

Educational experts often see the contribution of madrasas to human development as negligible (no student from the aliya madrasa has received a merit scholarship), more so in relation to educational assessments of low academic standards in the country in general, ${ }^{13}$ yet accounting for one-third of all new students (Bangladesh Economic Review, 2006), they cannot be ignored. Madrasas may lack a modern image, when viewed from a western, elite perspective, yet they are neither unified nor homogenous, as discussed above. Further, they are transforming themselves in a context of globalisation, contributing to material success, the acquisition of social status, and most importantly, they represent 'a total social phenomenon, in which knowledge, politics and social networks interact in a complex and "generative" manner' (Hefner, 2007: 2). Their alternate vision challenges the dominant discourse by locating itself in the reality of poverty and the need to make a living with dignity and self-respect, highlights the importance of language learning in a global context and emphasises public ethics, morality and human values as a central element of learning. Language and literacy are here treated 'as social practices and as resources rather than as a set of rules (or competencies) formally and narrowly defined' (Street, 1999: 1).

While there remains a much smaller, elite stream of English education in the urban pockets of the country, the comparison in this paper is with state-provided secular schooling which has seemingly failed to respond to changing work contexts and aspirations, not providing skills perceived as relevant for joining the globalised economy, nor protecting the value systems seen as

\footnotetext{
${ }^{11}$ One needs to distinguish here between the local preference for madrasas, largely functional and status-oriented, and madrasas as the core of militant Islam or 'jihadi factories'. This latter association has sharpened post 9/11, due to the rapid growth of madrasas in the Pakistan-Afghanistan border. The causes are several: the influx of Afghan refugees, the inability of poor Pakistanis to access affordable education as well as donations from patrons in the Gulf states (Hefner, 2007). While the Gulf States do fund buildings and curriculum of some of the Quomi madrasas in Bangladesh, they do not necessarily support extremist teachings.

12 Bangladesh Jamaat-e-Islami is the largest Islamist political party in Bangladesh, and indeed in the subcontinent, seeking to incorporate an Islamic ideology into the state system. Several members of the party are alleged to have played a crucial role in the atrocities during the liberation war such as organized killing of intellectuals, genocide and violence against women, resulting in the party being banned soon after Independence. http://en.wikipedia.org/wiki/Bangladesh_Jamaat-e-Islami accessed on $25 / 8 / 2009$.

13 The Education Watch report noted that on average a quarter of students of class 10 did not participate in the public examination. From those who did, less than half were successful, the rate of success varying from 68 per cent in state secular schools to 54 per cent in aliya madrasas (Ahmed et al., 2005).
}

essential to an Islamic identity. The strengths of madrasa learning are however differentiated in local evaluations and narratives. ${ }^{14}$ While the aliya madrasa is associated with largely non-educational, globalised work contexts, that while harsh and demeaning in everyday terms, do contribute to class mobility and facilitate inroads into local power hierarchies; the hafezia contributes to religious learning, teaching and prestige. They together help constitute a new social reality by demonstrating competence in terms of culturally significant values and skills, not just in terms of material wealth, but equally a commitment to community values and welfare. While perhaps not receiving merit scholarships, madrasa graduates apparently perform as well (if not better) in their work contexts as those trained in schooled discourses in the village under study.

\subsection{Schooling exclusions: dealing with poverty and marginality}

As mentioned earlier, dropouts from the secondary school in Sujapur are high, with less than half the boys and quarter of the girls enrolled in grade 6 completing the secondary cycle. Talking to the teachers and former students provided some insight into why children dropped out from the secular schools. Educational expenses and poverty of the parents were cited as major reasons leading to students, especially boys, dropping out of school to look for work and employable skills (alongside the relevance of the curriculum itself discussed in the next section), but issues of distance, security and marriage were also raised, particularly in the case of girls.

Some students leave school because of the financial condition of their parents. They go to the fields, or then to the garment factories in Savar, Nabinagar and Dhaka. The boys in particular leave school and go to work in the welding shops (secondary teacher).

While villagers reported that sending a child to the aliya madrasa cost them 1000 taka per year as against ten times that amount in the high school, the Education Watch Household Survey 2005 notes that the per child cost in a government secondary school $(12,063$ taka) was almost three times the cost in a dakhil or secondary level aliya madrasa (4502 taka) (Ahmed et al., 2005). Extra fees have to be paid for tuitions, books, lab work, exams and sports, making costs heavy for boys and much higher than the stipend of 720 taka per year received by girls in grades 9 and 10 . With small land-holdings and few assets, for a majority of households, the aliya madrasa is not just cheaper, but also preferred for its location which enables the children to contribute to household chores and other agricultural tasks in the village before and after school. Its location within the village is also seen to ensure safety and security, especially for girls, with parents and teachers pointing out that girls in particular were often harassed on their way to and from the school at Sujapur.

A related issue is one of community ownership and control, and the construction of a valued social identity. This is a response to at least two external developments: first, the lack of control over and accountability of state educational institutions and second, the need to build community cohesion in a context where there is persistent tension between collective strategies and individual aspirations, with people increasingly led to develop individualised strategies for their survival and mobility (Bauman, 2007).

Most of the children are studying in the aliya madrasa because it is within the village. It was our moral responsibility to

\footnotetext{
${ }^{14}$ Conducting an assessment of the returns to skills provided by different types of educational institutions is beyond the scope of this paper.
} 
establish this madrasa. A lot of money and labour has gone into it, so people feel socially and religiously obliged to send their children here. It is possible to learn everything from the madrasa, to know about the existing world and hereafter, which is not the case with general education (teacher at the aliya madrasa).

The madrasas in the village were set up as a result of local initiatives, hence the commitment to their success is strong, and there is considerable moral pressure to support them. While the aliya madrasa is state-funded, the hafezia is run entirely on public donations, with students seeking their daily food from the village community. Easy access and community pressure however are not sufficient for attracting students and keeping them in school; the aliya madrasa in particular therefore also attempts to construct a discourse of quality education.

\subsection{Meaning-making: the importance of language and moral values as markers of quality}

There are several issues that can be included as key elements of quality - here I briefly discuss the quality of teachers and the student-teacher ratio, the nature of the curriculum and type of knowledge generated, and the emphasis on language learning.

Teachers in both the madrasas and the secular school appear to have equivalent qualifications up to graduate or post-graduate levels, though acquired within different educational systems. Interestingly, in comparing the attitudes of teachers by school type and gender in Bangladesh, Asadullah and Chaudhury find that while madrasa teachers expressed a preference for larger families, favoured boys for higher education and political leadership and supported religious values and religious leaders in public life, the attitudinal differences with secular school teachers were not large, rarely exceeding 10 percentage points (2010: 208).

The madrasas lack library, computer and science facilities, yet in terms of learning environment, compared to the Sujapur high school with a teacher-pupil ratio of $1: 54$, the aliya madrasa has a ratio of $1: 25$ and the hafezia madrasa 1:37. This positive relationship is visible at the national level too, and during the BNP-led coalition rule, the teacher-pupil ratio in general schools was 1:27 against $1: 18$ in madrasas. Teacher-student ratio has been seen as a key element of quality education as it enables teachers to give more time and attention to each student. Though the madrasa teachers have hardly any exposure to teacher training, hence perhaps are less familiar with alternate pedagogies, especially those that are child-centred, the teachers of the aliya madrasa did provide extra tuitions to the weaker students in the mornings, before school, and during the Ramzan break. The hafezia madrasa, being residential, involves continuous interaction between the students and teachers. Being located in the village and overseen by the madrasa committee, the teachers in both cases are under pressure to ensure that some learning does take place. The provision of extra coaching to students in madrasas is confirmed by the Education Watch Report (Ahmed et al., 2005).

Apart from the quality of attention provided by the teachers, local narratives highlight the diversified curriculum adopted by the aliya madrasa, with an equal emphasis on general subjects, religion and morality and language learning.

It seems to me that madrasa education is better than general education from different point of views: firstly, the value of madrasa education and general education is the same up to grade 12 . Additionally, the government has now announced that fazil and kamil levels would be equivalent to BA and MA. Secondly, all kinds of curriculum are taught in the madrasa particularly in the Aliya madrasa which are absent in general education. There is an equal emphasis on general subjects and religion. Thirdly, the madrasas strongly inculcate religious values in the students. They pray to Allah for their parents and relatives, and this religious content of the curriculum is valued by parents (Aliya madrasa teacher).

The aliya madrasa, as noted above, teaches a range of general subjects such as maths, history and Bangla, and in this sense runs parallel to the secular schools. While science subjects are largely missing and critical thinking not encouraged, they do prepare interested students for higher education. Others gain at least basic literacy and numeracy skills. The hafezia madrasa focuses exclusively on Quranic learning, preparing students for jobs as imams in mosques and even teachers in madrasas. In contrast, there is an implicit questioning of the value and relevance of secular education.

Schools do not attract the children, the curriculum is neither interesting nor enjoyable and students often don't understand their lessons. If the curriculum was relevant, poverty would not stop children from school. Apart from poverty, people realise that for the types of jobs they want, 10th class is not sufficient, a minimum 12 years of education is required, perhaps even more. Given the costs, many decide to drop out after the 8th or 9th (secondary teacher at Sujapur school).

Evidence on labour market returns to education in Bangladesh reveals that unlike in other South Asian countries, returns to primary and secondary education are not substantially different and only increase with higher levels of education (Asadullah, 2005). Six families, who could afford private education, have moved from the village to nearby towns to provide better quality, higher education to their children, but this is beyond the reach of a majority of rural students from poor households. Secondly, while schooling does have a positive impact on the earning function, the type of school does not seem to matter much, with private, religious and NGO schools all revealing a negative correlation (Asadullah, 2009). This is because while secular schooling is seen to represent modern values and meritocratic rules, merit no longer seems an adequate criterion for securing a job, one with long-term security, benefits and prospects large amounts of money are required to pay bribes, or connections at high levels - and this the poor lack (Jeffrey et al., 2008). The government recognition of madrasa education as equivalent to secular education, despite the near-absence of science teaching in the curriculum, has also removed any incentive students may have to spend more money and put in greater effort to attaining what are seen as the same credentials.

While the relevance of the curriculum is an important issue, where the aliya madrasas score over secular schools is in emphasising a mindset governed by Islamic principles. There is a widespread perception that madrasa students are more religious-minded, and conduct themselves with honesty and morality due to a fear of Allah. Students here are taught to both respect and sacrifice for others, to be selfless, simple, self-sufficient and with a concern for social justice (Lukens-Bull, 2001: 360). They develop the capacity to be patient and steadfast under difficult conditions; work contexts increasingly tend to be harsh, demanding and providing few benefits. Largely involving manual work, they do not require high levels of literacy or educational credentials. ${ }^{15}$ As teachers, parents and young people all observed, it is only the constant reminder of their sacrifice for their families

\footnotetext{
$\overline{15}$ Class 8 is the official requirement for working in a garment factory, though this criterion is not rigidly imposed; fake certificates are easily manufactured at the factory gates.
} 
and the faith that Allah will bless them in both this life and the next, which keeps them going.

A third dimension of the curriculum relates to language learning. Under colonial rule, an English-vernacular (in this case Bangla) dichotomy was set-up, this was resisted post-Independence, by throwing out English altogether from the curriculum and from daily use. Such a situation however is not tenable in a globalised world; Bangla alone is not enough for survival, and expanding one's language skills become critical. Rather than opting again for English, there has been an emphasis on learning the Quran in Arabic, given the contingent benefit of exposure to Quranic Arabic for those who migrate to the Gulf. ${ }^{16}$

My brother and uncle have migrated to Saudi Arabia. Both of them studied in madrasas and learnt Bangla and Arabic. Arabic is less emphasised in general education. This gives them some advantage as they can understand the local language somewhat, better than most people from Bangladesh (Dilbar, 19, student).

Even if these language skills are not of a high standard and learned without reference to understanding the words or grammar, as the basis for Arabic learning is to read/recite the Quran, the simultaneous focus on Bangla and Quranic Arabic in the madrasas appears to give these students some advantage in relation to those who do not have any familiarity with Arabic whatsoever. Language appears to shape the ability to participate rather than transmit knowledge per se, as evident from the experience of several young men working in the middle-east, subjected to cheating and harassment by their employers, who felt that they could perhaps have better negotiated with the employers, administrators and the police if they had known Arabic and could speak to them directly rather than through mediators. Muzaffar, who migrated to Saudi Arabia for welding work, is a case in point. Not given his dues, he was unable to effectively negotiate with his employer, losing his work permit and ultimately being deported from the country. When and how to use linguistic resources, here becomes a key competence, contributing to occupational success.

Arabic learning is mainly associated with the knowledge of Islam, and parents believe that if their children follow the rules of Islam, they would go to heaven. The Quran is ultimately seen as the locus of both religious and worldly knowledge, it teaches one how to behave in a civilised and humane manner, at all times. But the expectations here are gendered; while the primary purpose of learning Arabic for men is seen to be its relevance in adapting to their work contexts, both for everyday communication (even though the forms of Arabic vary greatly, the common perception is that Quranic learning enhances familiarity with the language and makes it easier to grasp its spoken variants) and in terms of the values and morality it represents, for women, the ritual element is emphasised, with the memorisation and recitation of the Quran seen as a desirable feminine trait (Maddox, 2007).

The choice of language has a social meaning in terms of its use in different domains of one's life such as work, family and religion, but equally it has a symbolic function indicating both group membership and personal identity (Herbert and Robinson, 2001). At the institutional level, the struggle over language reflects a larger struggle between the state and the religious leaders for control over the education system, a key institution involved in reproducing social inequalities, but equally carrying the potential

\footnotetext{
${ }^{16}$ This is not to deny the importance of English, which as a global language of the powerful, has been adopted by most private schools in Bangladesh, but the roles and domains of English and Arabic are different. A detailed discussion of this issue is beyond the scope of this paper.
}

to create new identities, is this case, a modern, Islamic identity. At the personal level, madrasa education is given a positive meaning in terms of its social usefulness as well as cultural heritage, with the attention from teachers, a focus on character development within the curriculum and an emphasis on learning Bangla and Arabic, leading to the creation of a new identity that is capable of challenging existing socio-economic hierarchies and inequalities, both at home and in the workplace.

Madrasas may not engage with the latest developments in science and technology, yet in practical terms, they meet the needs of basic literacy (intrinsic value), provide some language skills (instrumental value), and most importantly, emphasise a particular view of morality and family that can help retain an element of social cohesion in a globalised world characterised by uncertainty and insecurity (social value). While recognising the social limits to their own cultural-linguistic resources, its inability for instance of preparing them to engage fully with the knowledge economy, rather than silencing themselves, the people here resist elite secular education through patronising and discursively legitimising perhaps the only alternative open to them (Levinson and Holland, 1996).

\subsection{Gendered uses: pathways to future security}

In contexts of poverty and insecure livelihoods, a critical outcome of the educational process is seen in terms of its employment potential. In a largely patriarchal context, with widespread wage discrimination in the labour market, women on average earning 60 per cent of men (World Bank, 2007), the provider role is largely ascribed to men. The ability to make a good marriage becomes the primary strategy for future security for women. These goals signify the acquisition of particular sets of skills - basic literacy for both, additionally moral values including tolerance, tenacity and patience for men and home-making, caring and religiosity for women. In this section, I seek to unravel how madrasas appear to better meet these outcomes in the contemporary context. Compared to the older generation in the village, in the early/mid 1990s, when a majority of those receiving secondary education did so in the high school (61 boys and 50 girls as against 33 boys and 11 girls in the madrasas), we find a reversal at present, with only 19 boys and 18 girls from the village currently attending the high school. In contrast, one finds 42 girls in the aliya madrasa, and 44 boys divided between the aliya and hafezia madrasas (see Table 1 ).

Historically, education was seen to lead to white-collar employment, though there was a marked distinction between the potential of secular, English education and religious, vernacular education to do so. Public sector employment is no longer a real option or even aspiration for the majority; hence educational alternatives that enable them to engage with the global markets are being explored. Apprenticeship is one route (Rao, 2009b), but one also finds a range of employment possibilities for those educated in madrasas - from religious work to manual work (preferably overseas) and selfemployment. Interestingly, while public sector employment is an acceptable option for women, most of these other alternatives are almost exclusively male. Amongst the poorest, women do find employment in the export oriented garment factories. This is however looked down upon, they are seen as 'spoilt' and it disqualifies them from making a good marriage.

\subsection{White-collar, religious work}

Analysing the employment profile of men in Achingaon, and their educational backgrounds, one finds that out of 22 in professional employment, 15 were educated in hafezia madrasas, working now as madrasa teachers and imams in mosques. The rest have qualifications from aliya madrasas, though some of them have tried to additionally gain secular qualifications. 
I studied maktab in Achingaon. Afterwards I passed hafezia in Dhaka, and then studied Nazra from Islampur. I got my first job soon after as an Imam in Pabna district. I got 500-700 taka salary per month. Accommodation and food was free. I then moved to a mosque in Kalampur where the salary was 1200 taka. I have moved to different mosques, getting a job has never been a problem. I always teach students and earn about 1000 taka per month in addition. While the salary may not be high, there is a lot of respect and one is not in desperation as all basic needs are met (Hamir, an Imam).

I passed dakhil in 1981 from my village, Alim from Char Jamalpur Islamia madrasa in 1983 and fazil from Sharifbag madrasa in 1985. The same year I applied for the job of a junior teacher in the Achingaon aliya madrasa and was selected. In 1996, I passed my kamil examination from Chandpur district and was then promoted as senior teacher. Yet I also enrolled in the Government College in Manikganj as a private student for a BA degree (Shamsher, 40, Aliya madrasa teacher).

What emerges from these narratives is that hafezia education almost certainly leads to a job as an imam in a mosque and while not high-paying, does endow the person with considerable social respect and cultural capital, hence remains popular. Such religious work is not perceived as employment of the last resort, but as Jeffrey et al. note, "a prize obtained through conscientious labour and the blessings of Allah" (2008: 155). Education from aliya madrasas, if pursued till the Fazil (BA) level, also appears to ensure jobs as madrasa teachers, and given the rapid growth of madrasas over the last decade, it is not surprising that the primary destination of madrasa graduates are mosques and madrasas (c.f. Asadullah and Chaudhury, 2008). In fact, professional employment and 'regular jobs' for men in the village are more or less restricted to teaching in madrasas and religious work as imams of mosques.

\subsection{Migration}

Apart from professional work, a majority of madrasa-educated men are engaged in migrant work both within the country and overseas. ${ }^{17}$ Overseas migration has a higher status than manual labour in the locality - it brings higher returns (migrants often returning home with consumer durables), is able to attract loans and contributes to constructing a respectable lifestyle and identity (adopting elite practices).

If someone works hard, he can earn much more than is possible locally, and this money can be used for family maintenance, for buying land or investing in a business. We can do any sort of job abroad that is not possible locally due to the issue of prestige. It is easier to get a loan for going abroad than for starting a business locally, as the lender knows that the migrant will work hard to earn the money and repay the loan. Education does not really matter, as we all end up with a range of labouring tasks (Kamal, an overseas migrant worker).

While secondary schooling can enable better jobs, even in the Gulf, as Rahman, the secretary of WARBE (Welfare Association of Repatriated Bangladeshi Employees), an organisation to support overseas migrants, noted, there seems to be a preference amongst the sending agencies, including the government run BOESL

\footnotetext{
${ }^{17}$ Out of 30 Gulf migrants from Achingaon, seven had studied up to grade 6 and beyond in general schools and four in madrasas. Information for five is missing. Most of the remaining 14, classified as non-literate, had attended the informal class run by the mosque to learn the Quran. While their Arabic skills are questionable in practice, familiarity with particular words was claimed.
}

(Bangladesh Overseas Employment and Services Limited) and the Bangladesh Association of International Recruiting Agencies (BAIRA), an association of private agencies, for sending unskilled workers. He said,

I gave money to an agent to prepare my papers, but when I went to collect them, I found the name and details did not match. I therefore refused this offer, but also lost the money I had paid. I then studied for a few years and got an administrative job in Saudi Arabia, but there found that many Bengalis were facing the same problem. The agents preferred recruiting less educated people for unskilled labour jobs as they are able to extract more commission from them. The papers are often not in order, hence there is no way a worker can protest or lodge a complaint if he/she does not get proper wages. Dual contracts are made - the papers show particular jobs, but on arrival they are usually engaged as manual workers at much lower wages.

This bias is also clear from an analysis of overseas migrants by skill level. Close to half of them (47 per cent) are unskilled workers (housemaids, hotel workers, agricultural workers and menial labourers), another 17 per cent semi-skilled (tailors, masons, etc.) and less than 5 per cent are professional workers (Siddiqui, 2005). While one could speculate on the political reasons for promoting unskilled labour migration, requiring low levels of education and passive acceptance of hard working conditions, from the country, migration nevertheless is also represented as an adventure to a new land, which only 'smart' people can cope with.

Geographical mobility here has a connotation in terms of certain key life skills, including the ability to negotiate and survive in unknown contexts (Piketty, 1995). And here perhaps there is a contradiction with madrasa education, which is seen as promoting religious-mindedness, fear and subservient attitudes rather than smartness or the image of modernity in terms of dress, language and lifestyle. Smartness, however, does not derive from educational credentials; rather migration itself becomes a form of learning basic survival skills and of coping in new environments. Madrasa education, by setting up locally distinct conceptions of what it means to be an educated person in terms of moral character, what constitutes socially relevant, respectable and appropriate learning in terms of humility and dignity of work, does open the way for picking up new ideas and skills and adjusting to new cultures. In the process it also challenges formal, statesponsored and elite representations of status and respectability.

Within a generation, successful migrants' households display symbols of material wealth (such as a brick house), but equally symbols of elite status reflected in (religious) activities such as contributing to the mosque or organising community events. Islam and knowledge of the Quran gained from madrasas seem to emphasise the importance of collective action. Several narratives on the use of migrant remittances emphasised this element, for instance, Karim's father noted that,

Small donations were made to the mosque and madrasa (1500 taka each), and we gained substantial social prestige by sacrificing a cow worth 10,000 taka during the Eid festival. I hope to use the remittances that follow to construct a large brick house, but more important, I want my son to undertake the hajj pilgrimage to Mecca before returning to Bangladesh.

The forms through which elite status is reflected can vary: some more traditional such as giving charity during the holy month of Ramzan to those in need; others more modern, such as using one's mobile phone to pass on information about jobs and wages to fellow villagers. By emphasising honesty, sacrifice and caring for others, madrasas attempt to set up an alternate vision of life that 
both challenges and attempts to transform the disembedding nature of the global hierarchies of work and life. Gardner (1995) however notes that alongside material remittances, the influx of religious ideas from abroad, especially the middle-east, tend to be conservative (criticise local practices, enforce restrictions of women's mobility), and this perhaps is responsible for status symbols to be framed increasingly in religious and communitarian terms. While there is indeed a re-centring of morality around Islam, and evidence of the growing domestication of women as discussed in the next section, this is accompanied by new forms of plurality in terms of educational processes and the recognition of alternate forms of learning, especially across spatial contexts, alongside new lifestyles and consumption as markers of status and identity.

\subsection{Domestication of women}

For men, in their working lives, the main priority appears to be gaining freedom and autonomy, with migration seen as a shortterm strategy to accumulate money to set up a business (selfemployment) in the village. They attempt to create a secure and respectable village home, with complete control and authority in their domestic lives, to counter the insecurity and difficulties they face in the workplace. The performance of nurturing roles by women in the domestic realm and total obedience to their husbands is essential to fulfill this goal.

A majority of the women in the village are classified as homemakers, there are only two in professional employment; amongst the poorest, 15 young, unmarried women are working in the factories, and two older women have migrated overseas for domestic work. The factory girls have studied till grades 7 or 8 in the aliya madrasa, while the older women are often classified as illiterate, despite having undergone a few years training in Quranic learning.

I never went to school, but when I was small I went to the masjid council to learn to read the holy Quran in Arabic language. From that time I can read the holy Quran. In Bahrain, at first I could not understand what the household members were saying but as I knew some Arabic, I could learn it quickly (Zahera, 38, domestic worker).

Zahera is the main provider in her household, yet her learning is hardly recognised. She however challenges the primacy of schooled learning by emphasising how her reading of the Quran familiarised her with the Arabic language. Yet she is an exceptional case in terms of her status as an overseas migrant. With a majority of migrants being male, ${ }^{18}$ roles and responsibilities have indeed become even more strongly demarcated by gender, with men responsible for public engagement and household provisioning and women for household maintenance and care in the private realm. Educational choices too are then gendered, with a preference in Achingaon, for girls to be schooled in the aliya madrasa. In fact, there are increasing instances of young wives who have been schooled in madrasas for longer than boys, ${ }^{19}$ though they usually drop out before taking the dakhil examination. Not taking the school leaving examination, hence lacking the credentials, implies that they pose no threat to their husbands in terms of formal qualifications. The emphasis of learning for girls

\footnotetext{
${ }^{18}$ Following a few incidents of sexual assault, the Government of Bangladesh had banned female overseas migration in the mid-1990s. This ban was lifted in 2002 following the establishment of the Ministry of Expatriates Welfare and Overseas Employment (pers comm. from Tasneem Siddiqui, 24th March 2007, Dhaka).

19 A World Bank Study (2008: 48) found a third of younger women more educated than their husbands.
}

here is on imbibing the values of patience and sacrifice, essential for dealing with long years of separation on the one hand, and having sufficient literacy and numeracy skills to take over the responsibility for home-making and social reproduction, on the other.

Herbert and Robinson (2001: 127) note that, "Islamic practices centre around the reading of the Quran in Arabic. In the Quran the Arabic word for 'read' is qara'a which also carries the meaning 'recite by heart'... This explains why many speakers of these languages perceive 'reading' as 'reciting by heart'". Proficiency in reading the Quran, with its implication of reciting by heart is seen as an essential qualification for a good woman and a good wife - she is not only literate, but trained in a non-questioning acceptance and repetition of the given word (Aftabuddin, 2006). There is a concern to create both pious and competent home-makers (Jeffery et al., 2004). A higher level of female schooling is hence not seen as a threat to male status. Rather it is seen as essential for the reproduction of the next generation - ensuring that wives not only follow their husbands' instructions long-distance, but also supervise the education of their children and inculcate religious values in them.

While men then have been able to use and represent madrasa education as a form of resistance and challenge to dominant, elite practices, through success in global work contexts overseas, women have not similarly been able to subvert dominant gender hierarchies. Rather the madrasas encourage them to support the male project and accept restrictions on their mobility and freedom within marriage as status markers, given particularly the lack of viable options for independent survival.

\section{Conclusion}

Madrasas in Bangladesh continue to cater largely to the poor, and not the elite, thus maintaining the dualism in the educational system inherited from colonialism. Yet the implications of madrasa education remain somewhat paradoxical. While posing a challenge to secular schooling and the power hierarchies inherent in formal learning, they contribute to preserving a hierarchical and feudalistic state that survives on a non-questioning population. While providing broader opportunities for men to engage more productively with the global economy, they result in a narrowing of social gender roles at home, confirming Levinson and Holland's view of the different and often contradictory ways in which gendered identities are signalled and gender privilege reproduced in varied global contexts (1996: 2). While secular schooling still carries value and is the aspiration in terms of intergenerational mobility, seen as the pathway for securing white-collar employment, what this paper has argued is that in a situation where the state is abdicating its responsibility of providing good quality and affordable secular education, and private education is beyond the reach of the poor majority, madrasas have come to represent a counter-culture, enabling the rural poor to acquire both social status and material wealth.

In terms of the representational dimension, the preference for madrasas is justified on several counts: the equivalence in credentials granted by the state, attention from the teachers, the emphasis on Arabic language learning and the focus on moral values and character development. While focus on morality and public ethics as an essential feature of literacy learning can be seen as a response to the pressures of global cultures and a strategy to cope with the new insecurities these bring, drawing on new Literacy Studies, I have argued that the content of learning itself is a cultural construct, and in this case, associated with the moral values of honesty, kindness and social justice. Madrasa education, with its focus on religion and sacrifice helps enhance the acceptability of performing degrading work, often under difficult conditions, within a global capitalist production system that 
requires cheap labour, justifying it through the construction of a positive identity and self-image as a provider, sacrificing physical comforts and putting up with loneliness for the sake of improving the material condition and status of the family.

A major issue that has emerged in the context of widespread migration and movement across countries, especially to the middle-east, is the need for some elementary knowledge of Arabic, an almost essential survival skill. While learning the Quran is compulsory in both madrasas and secular schools, there is a much greater emphasis on this in the madrasas, enhancing the chances of not just memorising the Quran, but also gaining some familiarity with Quranic Arabic. The focus on Arabic also has a symbolic function in challenging the hegemony of English as an international language in a post-colonial context, expressing a clear preference for one global language, which additionally represents an Islamic identity, over another. This view however is driven by the lack of choice for the poor as here too one finds a clear preference for English amongst the urban elite.

In terms of its communicational dimension, poor students are more likely to access and be successful in madrasas than in secular schools, both in terms of costs and learning expectations, and hence gain self-esteem, rather than considering themselves failures by the end of the educational cycle. Earning higher incomes in a global context enables them to gain confidence and overturn some of the starting inequalities and hierarchies, especially in terms of class position. New ways of acquiring elite status apart from education such as through contributions to the community, have gained legitimacy in the process.

While the interest in madrasas for specialists in education and development often arises due to a fear of the unknown, of seeing them as potential hotbeds for radical Islam, what this paper has sought to highlight is the diversity in educational strategies and their representation even within the madrasa sector that seek to challenge the dominant position of formal secular education and its attendant credentials. Despite what may seem to be the homogeneity of a group, cultural production is ongoing, and hegemonic definitions of the educated person contested along lines of gender, age, and in stratified societies, ethnicity and class (Levinson and Holland, 1996). Ultimately strategies for learning contribute to the development of a person's identity, in relation to work, but equally to the larger world. In the contemporary context of rural Bangladesh, madrasas appear to provide a positive framework for the construction of these identities to the poor compared to other forms of formal education.

\section{Acknowledgements}

The research was carried out as part of a larger project on Gender differences in Migration opportunities: Implications for educational choices and wellbeing outcomes, funded by the Development Research Centre on Globalisation, Migration and Poverty, whose support is gratefully acknowledged. I would like to thank participants at workshops at the University of Brunel, May 13-14, 2009 and University of East Anglia, September 1-3, 2009, for comments on earlier drafts, and Bryan Maddox, Shirin Zubair and Amit Mitra as well as the three anonymous IJED reviewers for their comments on this paper.

\section{References}

Aftabuddin, M. 2006. Perceptions, Motivations, Learning and Uses of Literacies in Relation to Livelihoods: A Case Study of Two Bangladeshi Villages. Ph.D. Thesis, Department of Education, University of Nottingham, Nottingham.

Ahmed, M., Nath, S.R., et al., 2005. The State of Secondary Education: Progress and Challenges. Campaign for Popular Education (CAMPE), Dhaka, Bangladesh.

Ahmed, M., Ahmed, K.S., et al., 2007. Access to Education in Bangladesh: Country Analytic Review of Primary and Secondary Education. BRAC University, Institute of Educational Development, Dhaka.
Asadullah, M.N., 2005. Returns to Education in Bangladesh. WP 130. Queen Elizabeth House, Oxford.

Asadullah, M.N., 2009. Returns to private and public education in Bangladesh and Pakistan: a comparative analysis. Journal of Asian Economics 20, 77-86.

Asadullah, M.N., Chaudhury, N., 2008. Holy alliances: public subsidies, Islamic high schools, and female schooling in Bangladesh. In: Tembon, M., Fort, L. (Eds.), Girls' Education in the 21st Century. The World Bank, Washington, DC pp. 209-238.

Asadullah, M.N., Chaudhury, N., 2010. Religious schools, social values, and economic attitudes: evidence from Bangladesh. World Development 38 (2), 205-217.

BBS, 2009. Updating Poverty Maps of Bangladesh. Bangladesh Bureau of Statistics. The World Bank, World Food Programme, Dhaka.

Bano, M., 2007. Allowing for Diversity: State-Madrasa Relations in Bangladesh. Religions and Development Working Paper 13, University of Birmingham, Birmingham.

Barton, D., Hamilton, M. (Eds.), 2000. Situated Literacies: Reading and Writing in Context. Routledge, London and New York.

Bauman, Z., 2007. Liquid Times: Living in an Age of Uncertainty. Polity Press, Cambridge.

Blanchard, C.M., 2008. Islamic Religious Schools, Madrasas: Background. Congressional Research Service, The Library of Congress, pp. 1-6.

Ellickson, J., 2002. Local saint vs contemporary reformer: religious trends in Bangladesh. In: Alam, S.M.N. (Ed.), Contemporary Anthropology: Theory and Practice. The University Press Limited, Dhaka, pp. 197-210.

Gardner, K., 1995. Global Migrants, Local Lives: Travel and Transformation in Rural Bangladesh. Clarendon, Oxford.

Gee, J.P., 2000. The new literacy studies: from 'socially situated' to the work of the social. In: Barton, D., Hamilton, M., Ivanic, R. (Eds.), Situated Literacies: Reading and Writing in Context. Routledge, London and New York, pp. 180-196.

Government of Bangladesh, 2006. Bangladesh Economic Review, Dhaka.

Guha, R., 2009. The rise and fall of the bilingual intellectual. Economic and Political Weekly 44 (33), 36-42.

Hartung, J.P., Reifeld, H., 2006. Islamic Education, Diversity and National Identity. Sage, New Delhi.

Hefner, R.W., 2007. Introduction: the culture, politics and future of Muslim education. In: Hefner, R.W., Zaman, M.Q. (Eds.), Schooling Islam: The Culture and Politics of Modern Muslim Education. Princeton University Press, Princeton, pp. $1-39$.

Herbert, P., Robinson, C., 2001. Another language, another literacy? Practices in northern Ghana. In: Street, B.V. (Ed.) Literacy and Development: Ethnographic Perspectives. Routledge, London and New York, pp. 121-136.

Jeffery, P., Jeffery, R., et al., 2004. Islamization, gentrification and domestication: a girls' Islamic course and rural Muslims in western Uttar Pradesh. Modern Asian Studies 38 (1), 1-53.

Jeffrey, C., Jeffery, P., et al., 2008. Degrees Without Freedom: Education, Masculinities and Unemployment in North India. Stanford University Press, Stanford.

Kress, G., 1996. Before Writing: Rethinking Paths to Literacy. Routledge, London.

Levinson, B.A., Holland, D.C., 1996. The Cultural Production of the Educated Person: Critical Ethnographies of Schooling and Local Practice. State University of New York Press, Albany.

Lukens-Bull, R.A., 2001. Two sides of the same coin: modernity and tradition in Islamic education in Indonesia. Anthropology and Education Quarterly 32 (3) 350-372.

Maddox, B., 2007. Secular and Koranic literacies in South Asia: from colonisation to contemporary practice. International Journal of Educational Development 27, 661-668.

Metcalf, B., 2007. Madrasas and minorities in secular India. In: Hefner, R.W., Zaman, M.Q. (Eds.), Schooling Islam: The Culture and Politics of Modern Muslim Education. Princeton University Press, Princeton, pp. 87-106.

Mitter, S., 1994. On organising women in casualised work: a global overview. In: Rowbotham, S., Mitter, S. (Eds.), Dignity and Daily Bread. Routledge, London and New York, pp. 14-52.

Munshi, K., Rosenzweig, M., 2003. Traditional Institutions Meet the Modern World: Caste, Gender and Schooling Choice in a Globalising Economy. Massachusetts Institute of Technology, Department of Economics, Cambridge, MA.

Piketty, T., 1995. Social mobility and redistributive politics. The Quarterly Journal of Economics 110 (3), 551-584.

Rahman, M., Bhattacharya, D., et al., 2009. Macroeconomic management in the face of global challenges. In: CPD Conference on Development with Equity and Justice: Immediate Tasks for the Newly Elected Government, Centre for Policy Dialogue, Dhaka.

Rahman, T., 2004. Denizens of alien worlds: a survey of students and teachers at Pakistan's Urdu and English language-medium schools, and madrasas. Contemporary South Asia 13 (3), 307-326.

Rao, N., 2009a. Gender Differences in Migration Opportunities, Educational Choices and Wellbeing Outcomes, Research Report, Development Research Centre on Globalisation, Migration and Poverty, University of Sussex. Brighton, p. 73

Rao, N., 2009b. 'I want to be respected': migration, mobility and the construction of alternate educational discourses in rural Bangladesh. In: Paper Presented at the Workshop on Learning, Livelihoods and Social Mobility. University of Brunel, May 13-14, London.

Siddiqui, T., 2005. International Labour Migration from Bangladesh: A Decent Work Perspective. International Labour Office, Geneva. Working Paper No. 66.

Street, B.V. (Ed.), 1993. Cross-Cultural Approaches to Literacy. Cambridge University Press, Cambridge. 
Street, B.V., 1999. New literacies in theory and practice: what are the implications for language in education? Linguistics and Education 10 (1), 1-24.

Street, B.V., 2001. Introduction. In: Street, B.V. (Ed.), Literacy and Development: Ethnographic Perspectives. Routledge, London and New York, pp. 1-17.

Street, B.V., 2005. Introduction: new literacy studies and literacies across educational contexts. In: Street, B.V. (Ed.), Literacies Across Educational
Contexts: Mediating Learning and Teaching. Caslon Publishing, Philadelphia, pp. 1-21.

World Bank, 2007. Bangladesh Gender Assessment: Celebrating the Victories, Addressing the Challenges. The World Bank, Washington, DC.

World Bank, 2008. Whispers to Voices: Gender and Social Transformation in Bangladesh. Bangladesh Development Series Paper No. 22. The World Bank, Washington, DC. 